\title{
The Impact of Working Capital Management on Profitability of Petroleum Retail Firms: Empirical Evidence from Ghana
}

\author{
Joseph Mbawuni $^{1} \&$ Mercy Hawa Mbawuni ${ }^{2} \&$ Simon Gyasi Nimako ${ }^{3}$ \\ ${ }^{1}$ Faculty of Business Education, University of Education, Winneba, Ghana \\ ${ }^{2}$ Kwame Nkrumah University of Science and Technology, Business School, Kumasi, Ghana \\ ${ }^{3}$ Department of Management Studies Education, University of Education, Winneba, Ghana \\ Correspondence: Joseph Mbawuni, Faculty of Business Education, University of Education, Winneba, Ghana. \\ E-mail: mbawuni@gmail.com
}

Received: March 10, 2016

Accepted: April 5, 2016

Online Published: May 25, 2016

doi:10.5539/ijef.v8n6p49

URL: http://dx.doi.org/10.5539/ijef.v8n6p49

\begin{abstract}
The study examined the impact of working capital management (WCM) on the profitability of petroleum retail firms (PRFs) in Ghana over a six year period (2008-2013). Audited annual reports from a sample of five selected petroleum retail firms in Ghana are employed in the study. Using, descriptive analysis, correlation and regression analysis, the results indicate that, in the PRFs in Ghana, there is favourable net working capital for the firms and a favourable networking capital to total assets ratio. The most important WCM component that drives the firm's profitability, measured in return on assets (ROA), is average days payable (ADP). The rest of WCM components, cash conversion cycle (CCC), average days inventory (ADI) and average days receivables (ADR) did not have significant relationship with profitability. The study further found that WCM practices among the five selected PRFs support the conservative strategy of WCM, rather than an aggressive WCM strategy. Theoretical and managerial implications are discussed.
\end{abstract}

Keywords: working capital, profitability, petroleum firms, return on assets, regression analysis

\section{Introduction}

One of the key determinants of survival and sustainable business growth of modern organisations is the effectiveness of accounting and finance department or function (Eljielly, 2004). One area of accounting and finance that affects the efficient operations of business organisations in general is working capital management (WCM), among other things (Eljielly, 2004; Shin \& Soenen, 1998; Tauringana \& Afrifa, 2013). WCM has been described as the management of current assets and current liabilities (Agyei \& Yeboah, 2011; Tauringana \& Afrifa, 2013). The concept of WCM addresses companies' management of their short-term capital, which is an important component of corporate financial management, directly affects the profitability and liquidity of both small and large firms (Agyei \& Yeboah, 2011; Tauringana \& Afrifa, 2013). It has been well noted that small scale industries contribute immensely to providing job opportunities, nurturing a society of entrepreneurs and opening up new business avenues for the development of a country.

The global financial crisis in 2008 caused businesses, lenders, insurers and governments to re-evaluate their situations, taking steps to protect themselves for now and the years to come. (Global Working Capital Annual Review - GWCAR, 2013). According to the Institute of Statistical Social and Economic Research (ISSER, 2014), this financial crisis has had some significant impact on many African economies including Ghana. In this global economic trend, working capital management has been a top priority of many firms. According to the Global Working Capital Annual Review (GWCAR, 2013, p. 39), 49\% of company boards focus greatly on cash and working capital as top priority for corporate growth strategy. According to the GWCAR report, overall, working capital levels have deteriorated year on year by almost $2 \%$ globally, a trend that is reflected across all industry sectors. Moreover, globally, the highest levels of working capital are seen in Pharmaceuticals and Manufacturing driven by both high levels of inventory and debtors, and whilst Utilities, Retail and Technology sectors have experienced the greatest deterioration year on year. The greatest improvement was seen in Oil and Gas with an already low level of working capital. The need for firms to maintain optimum working capital and creating sustainable working capital is becoming ever more important. 
Consequently, proper working capital management would enable firms sustain business growth, which in turn leads to maximisation of owners' wealth in many industries in general, for that matter developing countries' petroleum companies in particular. This study focuses on working capital management and profitability analysis among petroleum retailers in Ghana. With the current down turn of world fuel prices and the turbulent economic conditions prevailing in Ghana, coupled with high interest rates, high inflation, fluctuating fuel prices, and the depreciation of the Ghanaian cedi, it is only expedient that resources are wisely managed by firms. Companies have to be conscious and employ the source of funding often neglected by most managers in the form of working capital. For instance, companies could make use of the credit facilities given by their supplies.

WCM is an area of interest that has seen wide coverage by the academia in order to postulate firm's profitability. Many researchers have deliberated on WCM in so many different ways. As some authors focused on the impact, of the optimal inventory management, others looked at the best methods of managing account receivables and account payables that gears towards profit maximization, (Lazaridis \& Tryfonidis, 2006). Similarly, other studies have deduced that reduction of WCM, improves firms profitability (Jose et al., 1996; Shin, 2007). There is a general consensus in existing financial accounting research that inefficient management of working capital causes failure of small firms (Berryman, 1983), as well as overtrading (Appuhami, 2008), liquidity and profitability problems(Eljielly, 2004; Peel \& Wilson, 1996; Shin \& Soenen, 1998). In spite of the critical importance of WCM to business organisations in general and petroleum retail companies in particular, very limited research has been conducted to explore WCM in petroleum companies. Most empirical studies on WCM are based on large corporate institutions in developed economies (Deloof, 2003; Shin \& Soenen, 1998; Tauringana \& Afrifa, 2013).

A relatively few studies have examined WCM in specific small scale industries such as in manufacturing, the retail sector, agriculture among others in developing countries in general, like Uganda (Orobia et al., 2013), Nigeria ( Oladipupo \& Okafor, 2013), Zimbabwe ( Zawaira \& Mutenheri, 2014), and Ghana's financial industry( Agyei \& Yeboah, 2011).The findings of previous studies also show major inconsistencies in WCM and profitability relationship (Deloof, 2003; Ganesan, 2007; Gill et al., 2010; Islam \& Mili, 2012).

No study to the best of the knowledge of the researcher has been done to examine WCM and its impact on profitability in Ghana's petroleum industry. This research will therefore provide empirical evidence on the effect of WCM on profitability in petroleum retail firms (PRF) in Ghana, which is an under-researched area of study. Therefore, the main problem of this study is to investigate the extent to which WCM affects profitability of petroleum retail firms in Ghana, the experiential proof on the working capital management and its impact on the firm performance in PRFs also serves as an inspiring force to study the subject matter in detail. Again, some managers in Ghana PRFs tend to ignore the organisation's operating cycle thus having extended debtors' collection period and shorter creditors period. All these are the stimulating forces which call for an investigation, hence the need to study the effects of working capital management on the profitability of PRF in the Kumasi metropolis. The main purpose of this study is to assess the impact of components of working capital management on the profitability of PRFs in the Kumasi Metropolis in Ghana.

\section{Literature Review}

\subsection{Concept of Working Capital Management}

The term working capital (WC) has several meanings in business accounting and finance. From the perspective of accounting and financial statement analysis, working capital is defined as the firm's short-term or current assets and current liabilities (Arnold, 2008; Jeng-Ren et al., 2006). On the other hand, from a financing perspective, working capital refers to the firm's investment in two types of assets, a firm's investment in short-term (current) assets needed to operate over a normal business cycle, and a company's investments in overall non-fixed assets that are not often measured on the balance sheet such as investment in product redesign or formulation of a new marketing strategy (Bevan \& Danbolt, 2002; Sogorb-Mira, 2005). This study focuses on the accounting and financial statement analysis perspective of WC, which focuses on current assets and current liabilities measured on the balance sheet. In the chosen perspective of WC, there are two further meanings or perspectives of working capital, gross working capital and net working capital. Gross working capital is a quantitative perspective which defines WC as the total current assets of a firm (Khan \& Jain, 2007), while net working capital is a qualitative perspective which defines WC as the excess of current assets over current liability of a firm (Khan \& Jain, 2007). Net working capital, therefore, represents the amount of current assets that would remain if all current liabilities of a firm are paid for. These two perspectives of WC have their respective areas of significance. The 'Gross concept' is useful where the purpose of financial management is to measure the size and extent to which current assets are being used, whereas 'Net Working Capital' is preferable and useful where the aim is to evaluate the liquidity position of an undertaking. In this study, since the focus is on analysis of WC and profitability relationship which is 
part of the liquidity of the firm, it becomes appropriate and useful to adopt the Net working capital (NWC). Thus NWC as used in this study refers to Net working capital, which is defined as "the difference between current assets and current liabilities" (Arnold, 2008, p. 515). This choice of definition is also consistent with many studies that examined the impact of WC management on liquidity, profitability or productivity of companies (Abosede \& Luqman, 2014; Agyei \& Yeboah, 2011; Lazaridis \& Tryfonidis, 2006; Orobia et al., 2013; Tauringana \& Afrifa, 2013).

Managing working capital includes all aspects of the administration of current assets and liabilities (Hofmann \& Kotzap, 2010). WCM is intended to minimize the capital to be tied up in the company's turnover process by reducing current assets and extending current liabilities. In facilitating WCM, strategic managers use various approaches to enable them monitor their optimal WC levels. Cash conversion cycle (CCC) is one of the most used measures in WCM analysis, which has four main components (Arnold, 2008; Gitman, 2009), which are inventory management, accounts receivables, cash management and accounts payables.

\subsection{Empirical Review of WCM and Profitability Relationship}

Many past studies have been conducted to examine the relationship between WCM and firm performance and/or profitability from different industry contexts. Tauringana and Afrifa (2013) studied the relative importance of WCM among 133 SMEs in the UK for the period 2005 to 2009. Using panel data regression analysis of a sample of 133 firms, their results show that the management of average days payables (ADP) and average days receivable (ADR) is important for SMEs profitability. However, generally, CCC and WCM relationship was non-significant. The relationship between average days inventory (ADI) and return on assets (ROA) was negative but not significant. ADR was negatively related to profitability significantly and that ADP is negatively associated with profitability. Regarding relative importance, ADR management was rated top most priority, followed by ADP, ADI and CCC. Their study was limited to listed SMEs, and therefore the findings lacks generalisability to all companies. They suggest that the SMEs need to concentrate their limited resources on managing average receivables (AR) and average payables (AP) in order to be more profitable.

A relatively few studies have examined WCM and profitability relationship in the context Africa and Ghana in particular. Oladipupo and Okafor (2013) examined relationship between WCM and firm profitability and dividend payout ratio in Nigeria. Using financial data obtained from twelve manufacturing companies quoted on the Nigeria Stock Exchange over five years period (2002 to 2006), the results of Pearson product moment correlation technique and ordinary least square (OLS) regression technique indicated that shorter net trade cycle and debt ratio promote high corporate profitability. They further found that while the level of leverage has negative significant impact on corporate profitability, the impact of working capital management on corporate profitability appears to be statistically insignificant at 5\% confidence level. Also, dividend payout ratio was influenced positively by profitability and net trade cycle but negatively by growth rate in earnings. Moreover, the impacts of both corporate profitability and working capital management on the dividend payout ratio appear to be statistically insignificant at $5 \%$ confidence level.

Stephen and Elvis (2011) examined the effect of WCM on firms profitability using SMEs in Kenya. Using fixed panel data of 232 firms, the results indicated that the ADR, ADI and the CCC significantly affected the firms' profitability positively. This implied that SMEs in Kenya appear to be adopting conservative WCM policy. The firms needed to concentrate and improve their collection and payment policy. The findings also imply that the effective WCM policy formulation can positively affect manufacturing firms' operating profitability. They recommended that, for efficient working capital management, specialized persons in the fields of finance should be hired by the firms for expert advice on working capital management in the manufacturing sector.

Adjei and Yeboah (2011) studied how WCM practices are related to profitability of banks in Ghana. Using panel data from 28 banks, over a ten year period (from 1999-2008), the findings appeared to be inconsistent with some previous research on WCM and profitability relationship. They found that CCC and ADR were positively related to bank profitability, while ADP was negatively related to profitability. Also, credit risk, exchange risk, capital structure and size significantly increase bank profitability. They however found that firms that are quoted on the Ghana Stock Exchange seem to perform worse than their unlisted counterparts.

Akoto et al. (2013) studied the relationship between WCM and profitability of listed manufacturing firms in Ghana, using 13 manufacturing firms quoted on Ghana stock exchange spanning the period from 2005 to 2009. Using secondary data collected from all the 13 firms, the results showed a significantly negative relationship between profitability and accounts receivable days. However, there was a positively significant relationship between the firms' profitability and WCM factors such as CCC, firm size, and current asset turnover, and current asset ratio. The authors used return on equity as an approximation of profitability instead of return on assets. Their results 
suggest that managers can improve shareholders' wealth by putting in measures to reduce their accounts receivable to 30 days. Moreover they recommend that there should be establishment domestic regulations that protect local firms and prevent the activities of importers to promote increase demand for locally manufactured goods in Ghana.

\subsection{WCM and Profitability Relationship in Petroleum Industry}

There is very limited research in WCM and profitability relationship in the petroleum industry. Aruldoss et al. (2013) explored WCM of an Indian petroleum company from 2010-2011. Their findings show decrease in working capital for the firm in question but the profitability of the business shows a positive trend in favour of the company operations as it reflected in a positive working capital of the company.

Shah and Sana (2005) studied the impact of WCM on the profitability of oil and gas sector of Pakistan using seven listed firms companies for a five year period, 2001 to 2005. Applying correlation and Ordinal Least Square method using Fixed Effect Estimation model, the authors found a non-significantly negative relationship between gross profit margin and number of days inventory and number of days accounts receivable, but a positive, non-significant relationship between profitability and cash conversion cycle and sales growth. According the authors, the results show the existence of firm effect indicates the different management styles of the companies and different working capital needs. They believe that negative CCC is due to early settlement of outstanding payments. They also found sales growth to be negatively related to profitability, indicating abnormal results. However, this does not seem abnormal in Oil and Gas Sector as the initial investment is capital intensive.

Similarly, Raza et al. (2015) further examined the impact of working capital management on profitability in Pakistan oil sector using five companies for a five year period, 2006 to 2010. The authors provided a descriptive analysis of the current ratio, liquidity ratio and profitability ratios of the various companies studied but did not use a regression analysis to test the impact of WCM on profitability directly.

Sarkar and Sarkar (2013) researched into the impact of WCM on corporate performance in some selected public sector oil and gas companies in India during the period of 10 years (i.e. from 2000-01 to 2009-10). The authors used return on capital employed as a measure of profitability. Using descriptive and correlations analysis, they found that out of selected eight ratios, current ratio, current assets to total asset ratio and inventory turnover ratio for the six selected companies have the significant influence on the overall profitability of the concerned companies.

Again, the study of associations between Return on Equity and Performance Index, Utilization Index and Efficiency Index for the selected companies under study, have registered both positive and negative relationships, but these associations are not statistically significant at 0.05 and 0.001 levels of significance during the given study period. They found that the WC leverage ratios of the selected companies under study were fluctuating in nature during the study period and were less than unity during the study period.

In spite of some inconsistencies in findings, generally, much of the existing literature indicate that where a firm is unable to effectively manage its WC, the firm is likely to experience reduced profitability and other financial problems. Both low and high working capital might be disadvantageous for a business concern. While high net working capital can result in unused funds, which could be invested in other profitable ventures, the low net working capital could disrupt business operations and will also adversely affect profitability (Chowdhary \& Amin, 2007).

\subsection{Brief Review of Petroleum Industry in Ghana}

In 2004 Ghana began her offshore oil exploration by selling its licenses for exploration to different international companies (Kastning, 2011). According to the ministry of energy (MoE), in July 2007, Tullow Oil and Kosmos Energy discovered oil and gas in commercial quantities in the western region of Ghana in two blocks: Deepwater Cape ThreePoints and Deepwater Tano. They named the area "Jubilee Field". According to estimates findings from Offshore-Technology.com (2011), the Jubilee field can be found in the Gulf of Guinea, $60 \mathrm{~km}$ off the Ghanaian coast, near the Côte d'Ivoire border. The size of the oil field is $110 \mathrm{~km}^{2}$ (Offshore-Technology.com, 2011). Development of the production site started right away and in December 2010 oil production was officially launched. Since 2007 further discoveries have been made. The Tweneboa field seems to be a second major discovery. Appraisals conducted indicate that the field contains expected recoverable reserves of about 800 million barrels of light crude oil, with an upside potential of about 3 billion barrels (GNPC, 2008; Kastning, 2011).

The discovery provides Ghana an opportunity to reduce foreign exchange requirements for the importation of crude oil and also to increase export earnings significantly. The main strategic goal of the MoE to sustain exploration, development and production of the oil and gas endowment and also the judicious management of the oil and gas revenue for the overall benefit and welfare of all Ghanaians, present and future as well as attract 
increased local value-added investments in the oil and gas sector and the indigenization of knowledge, expertise and technology. The major challenges for the upstream petroleum sub-sector are how to develop the oil and gas industry with optimal local content and participation, and effectively manage the potential revenue from oil and gas production, and ensure security for the industry as a whole. In the upstream in the petroleum industry, there are relatively few extraction companies while in the downstream there are many intermediary companies operating petroleum retail firms. Tullow Oil and Gas is an independent Irish exploration and production company, quoted on the London and Irish Stock Exchanges.

In 2004 it acquired Energy Africa. Its headquarters are in London and it runs two offices in Accra. Kosmos Energy is an independent American Oil and Gas Exploration and Production Company. It was founded in 2003 by five partners. Anadarko Petroleum Corporation is one of the world's largest independent oil and gas exploration and production companies, quoted on the U.S. Top 500 Stock Exchange. Anadarko has its headquarters in The Woodlands, Texas, U.S. They do not have an office in Ghana. The Ghana National Petroleum Corporation (GNPC), which belongs to the Ghana government, was formed in 1985. It is regulated by the national petroleum authority (NPA) in Tema, Ghana. It owns a 10\% interest in the various Ghanaian offshore blocks. Therefore a $10 \%$ carried interest in the Jubilee field belongs to them. The GNPC runs the Tema Oil Refinery. (GNPC, 2011). Another extraction company is The EO (Edusei - Owusu) Group which was formed in 2002, by the Ghanaians Dr. Kwame Barwuah Edusei and George Owusu.

In view of the potential of the petroleum industry in Ghana, it has attracted a lot of retailing operations. Without effective WCM retailing firms in the petroleum industry in Ghana would find it difficult to make profit and survive. The tendency for some managers to ignore the organisation's operating cycle thus having extended debtors' collection period and shorter creditors' period can have adverse effect on WCM and profitability of the PRFs in Ghana.

\subsection{Conceptual Framework and Hypothesis}

Based on the review of literature on the relationship between WCM and profitability of firms in general, the conceptual framework for the study is developed (see Figure 1) and the hypotheses underlying the proposed relationship between WCM and profitability are discussed for empirical testing.

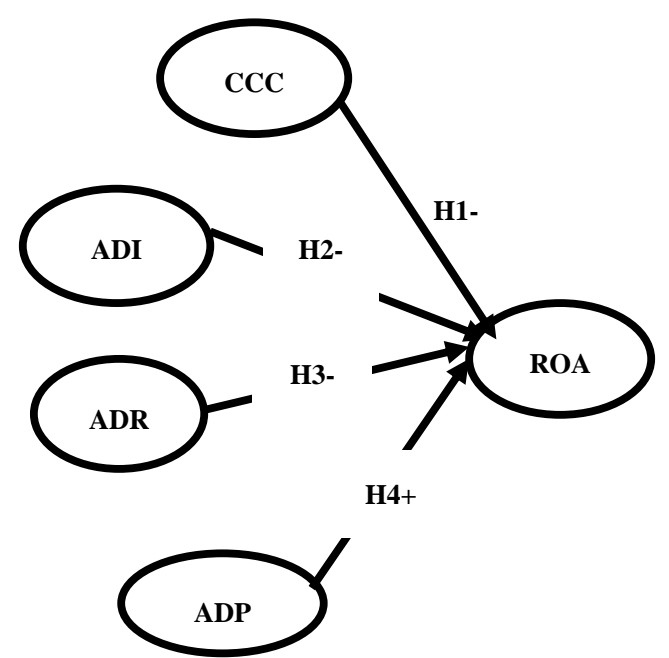

Figure 1. Conceptual framework and hypotheses

Notes. CCC - Cash conversion cycle; ADI - Average number of days inventory, ADR - Average number of days accounts receivable; ADP Average number of days accounts payable.

\subsection{Cash Conversion Cycle and Profitability Relationship}

WCM and profitability relationship might depend on the firm's WCM strategy (Garcia-Teruel \& Martinez-Solano, 2007; Nazir \& Afza, 2009; Tauringana \& Afrifa, 2013). According to Tauringana \& Afrifa (2013, p. 456) a firm that adopts an aggressive WCM approach, usually has a negative relationship between components of WCM and profitability, and should expect that ADP and profitability are positively related. For the conservative approach, it is expected that CCC, ADI, ADR and profitability will be positively related, and expect that ADP and profitability are negative related. The type of WCM strategy adopted by management might explain the contradictions of 
findings of previous studies on how WCM components are related to profitability. Previous studies examining how CCC and its components are related to profitability reveal inconsistent findings. Some previous studies found negative relationship between WCM and CC (Akoto et al., 2013; Lazaridis \& Tryfonidis, 2006; Falope \& Ajilore, 2009), which supports the aggressive approach to WCM. On the other hand, a positive and significant relationship was reported by Sharma and Kumar (2011), Gill et al. (2010), Adjei and Yeboah (2011), which supports the conservative strategy of WCM. Since the type of WCM strategy of petroleum retail firms used in this study is not known, it can only be expected that there is a significant relationship between WCM and profitability for the firms, but the direction of the relationship cannot be predetermined as used in previous studies (Tauringana \& Afrifa, 2013, p. 457). This leads to the hypothesis that:

H1: There is a significant relationship between cash conversion cycle and profitability.

\subsection{Average Number of Days Inventory (ADI) and Profitability Relationship}

There are also some contradictory findings on the relationship between ADI and profitability. In terms of inventory holding, some previous studies (Raheman \& Nasr, 2007; Nobanee, 2009) found that profitability and inventory holding component (ADI) of WCM are positively related, which is in line with the conservative approach to WCM. Tauringana and Afrifa (2013) even found no significant relationship between ADI and profitability. However, Deloof (2003), Raheman and Nasr (2007), and Falope and Ajilore (2009) all found that ADI and profitability are negatively and significantly related which suggests the aggressive approach to WCM. Since the type of WCM strategy of petroleum retail firms used in this study is not known, it can only be expected that there is a significant relationship between inventory holding (ADI) and profitability for the firms, but the direction of the relationship cannot be predetermined as used in previous studies (Tauringana \& Afrifa, 2013, p. 457). This leads to the hypothesis that:

\section{H2: There is a significant relationship between inventory holding period (ADI) and profitability.}

\subsection{Average Number of Days Accounts Receivable (ADR) and Profitability Relationship}

The relationship between accounts receivable and profitability are also contradictory. For example, some past studies found that profitability and accounts receivable component (ADR) are positively related, which is in line with the conservative approach to WCM (Raheman \& Nasr, 2007; Nobanee, 2009). Conversely, the findings of Deloof (2003), Raheman and Nasr (2007), Falope and Ajilore (2009) and Tauringana and Afrifa (2013) show that ADR and profitability are negatively related, which suggests an aggressive approach to WCM. Given that the type of WCM strategy of petroleum retail firms used in this study is unknown, it is expected that the relationship between profitability and ADR will be significant, but the direction of the relationship cannot be predetermined (Tauringana \& Afrifa, 2013, p. 457). This leads to the hypothesis that:

\section{H3: There is a significant relationship between accounts receivable period (ADR) and profitability.}

\subsection{Average Number of Days Accounts Payable (ADP) and Profitability Relationship}

Regarding ADP, existing research shows contrasting findings for the relationship between ADP and profitability. For example, some past studies found that ADP and profitability are positively related which is in consonance with the aggressive approach to WCM (Raheman \& Nasr, 2007; Tryfonidis \& Lazaridis, 2006). In contrast, the findings of Deloof (2003), Karaduman et al. (2010), and Tauringana and Afrifa (2013) support that profitability and ADP are negatively related, which suggests a conservative approach to WCM. Based on this review, it is not really obvious to determine whether aggressive or conservative approach to WCM are associated with profitability positively or negatively. Given that the type of WCM strategy of petroleum retail firms used in this study is unknown, it is expected that the relationship between ADP and profitability will be significant, but the direction of the relationship cannot be predetermined (Tauringana \& Afrifa, 2013, p. 457). This leads to the hypothesis that:

H4: There is a significant relationship between accounts payable (ADP) and profitability.

\section{Methodology}

\subsection{Population and Sampling}

The target population of this study was all registered petroleum retail firms in the Kumasi Metropolis who have prepared their audited financial statements for six years from 2008 to 2013. A sample of five selected firms were taken for this study. The data were taken from the companies but the names of the companies will remain anonymous in the research work. In order to ensure ethical research, the researcher assured them of the anonymity of their identity (Cooper \& Schindler, 2006). The choice of these firms was based on convenience since it was difficult getting other companies to release their financial statements for the research purpose. 


\subsection{Data Analysis Methods}

Data was analyzed using descriptive analysis, correlation, and panel data methodology available in STATA 12.0. The descriptive analysis involved the use of means, standard deviation, median and percentages to describe the dependent, independent and controlled variables for this study. The correlation coefficients using Pearson correlation was presented for all dependent and independent variables such as CCC and its components (ADI, ADR and ADP) and profitability measured by return on assets (ROA). Finally, panel data analysis was used within the framework of the random effects technique for the presentation and analysis of findings. Panel data methodology has the advantage of not only allowing researchers to undertake cross-sectional observations over several time periods, but also control for individual heterogeneity due to hidden factors, which, if neglected in time-series or cross-section estimations leads to biased results (Baltagi, 1995). Bartov et al. (2000) maintain that if confounding variables are not controlled, it could lead to biased results, such as not accepting the null hypothesis when it should actually be accepted.

\subsection{Panel Data Specifications}

In this study, panel data analysis is deemed appropriate since the study is interested in examining the causal relationship between different components of WCM measured with CCC (ADI, ADR and ADP) and profitability (ROA) for five different PRFs within six consecutive years, from 2008 to 2013. In view of the need to control some individual heterogeneity in assessing the effect of WCM on profitability, prior research suggests that variables like the inventory divided by current assets (ADI/CA), current assets divided by total assets (CA/TA), current assets divided by total assets (CA_TURN), leverage (LEV) and firm size measured by log of total assets (TALOG) are likely to affect firm profitability (Padachi, 2006; Stephen \& Elvis, 2011; Tauringana \& Afrifa, 2013). Therefore, these variables were controlled in the analysis. Moreover, the effect of company was also tested as suggested by previous research in oil and gas industry (Shah \& Sana, 2005). Firm effect was included as a dummy variable with E-LTD used as the base company and four dummies created for the other firms as D_JLTD, D_MLTD, D_LLTD, and D_SLTD respectively.

In this study, the balanced panel data was chosen over the unbalanced panel data. This is because balanced panel data allows for the equal observation for every unit of observation for each time period (Tauringana \& Afrifa, 2013). In panel data analysis, one important decision is whether to employ a fixed effects model or a random effects model. The random effects model assumes a single common intercept term, and that the intercepts for individual companies vary from this common intercept in a random manner, whilst the fixed effects model assumes different intercept for individual companies. Random effects panel data regression analysis will be chosen following similar studies (Karaduman et al., 2010, 2011; Tauringana \& Afrifa, 2013). The specific data analysis technique used is the multilevel mixed-effects linear regression model available in STATA 12.0.

\subsection{Regression Model Specification}

The regression analysis models developed for this study are intended to examine the relationships between WCM and its components and profitability. The definition for each term used in the equations are presented in Table 1.

$$
\begin{aligned}
& R O A_{i}=\beta_{0+} \beta_{1} C C C_{i t}+\beta_{2} Q R_{i t+} \beta_{3} A D I / C A_{i t}+\beta_{4} C A / T A_{i t}+\beta_{5} C A_{-} T U R N_{i t}+\beta_{6} L E V_{i t} \beta_{7} T A L O G_{i t} \\
& R O A_{i t}=\beta_{0+} \beta_{1} A D I_{i t}+\beta_{2} Q R_{i t}+\beta_{3} A D I / C A_{i t}+\beta_{4} C A / T A_{i t}+\beta_{5} C A_{-} T U R N_{i t}+\beta_{6} L E V_{i t}+\beta_{7} T A L O G_{i t} \\
& R O A_{i t}=\beta_{0+} \beta_{1} A D R_{i t}+\beta_{2} Q R_{i t}+\beta_{3} A D I / C A_{i t}+\beta_{4} C A / T A_{i t}+\beta_{5} C A_{-} T U R N_{i t}+\beta_{6} L E V_{i t}+\beta_{7} T A L O G_{i t} \\
& R O A_{i t}=\beta_{0+} \beta_{1} A D P_{i t}+\beta_{2} Q R_{i t+} \beta_{3} A D I / C A_{i t}+\beta_{4} C A / T A_{i t}+\beta_{5} C A_{-} T U R N_{i t}+\beta_{6} L E V_{i t+} \beta_{7} T A L O G_{i t}
\end{aligned}
$$

Table 1. Definition of research variables used in regression models

\begin{tabular}{ll}
\hline Profitability \\
\hline ROA & Return on assets, measured as profit before interest and tax for the year as a ratio of the total assets at the end of the financial year \\
\hline Working Capital Management \\
\hline CCC & $\begin{array}{l}\text { The Cash Conversion Cycle (CCC) is estimated as (ADI + ADR - ADP), which represents the average timing difference between } \\
\text { when a firm pays for its suppliers and the time it takes to recoup amount invested in debtors and inventory }\end{array}$ \\
& $\begin{array}{l}\text { Average days of inventory (ADI) calculated by dividing inventory by cost of sales multiplied by365 days. This represents the } \\
\text { average number of days a company is holding the inventory }\end{array}$ \\
ADI & $\begin{array}{l}\text { Accounts receivables (ADR) represents the average number of days the firm takes to collect receivables from customers. This is } \\
\text { ADR }\end{array}$ \\
ADP & $\begin{array}{l}\text { Average days accounts payable (ADP) is the average number of days it takes a firm to pay trade creditors. This is computed by } \\
\text { dividing accounts payables by cost of sales multiplied by } 365 \text { days }\end{array}$ \\
\hline
\end{tabular}




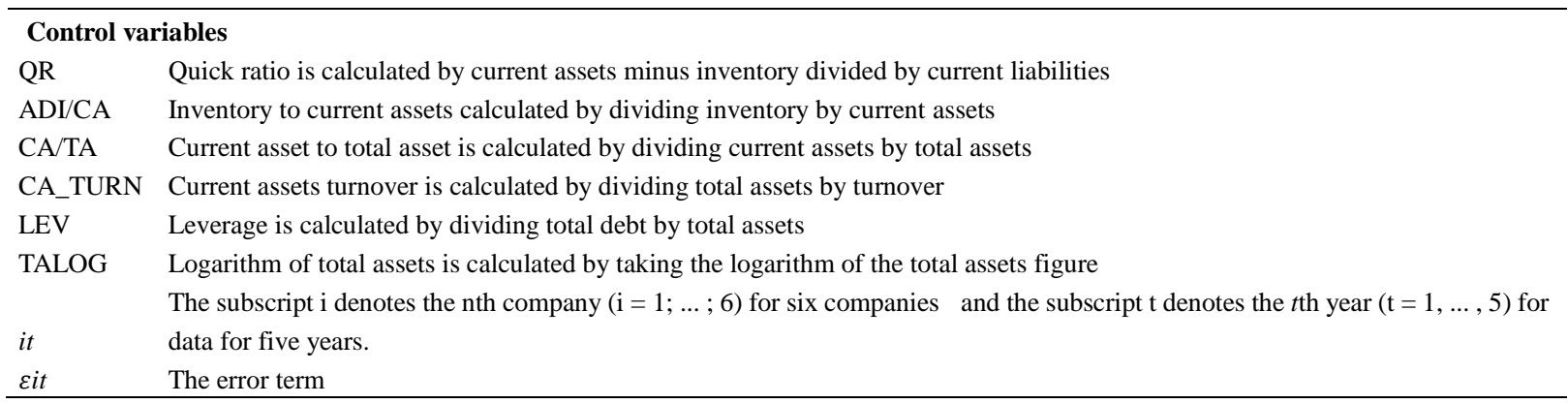

\subsection{Descriptive Analysis for Dependent and Independent Variables}

\subsubsection{Dependent Variable: Profitability (ROA)}

The descriptive analysis for profitability, measured by return on assets (ROA), is presented in Figure 2 for each firm. It shows that the mean return on assets (ROA) is $17.32 \%$ for the five firms. Among the firms, J-LTD recorded the highest ROA $28 \%$, followed by $24.33 \%$ for M-LTD, $15.4 \%$ for L-LTD and E-LTD and S-LTD recorded $9 \%$ and 9.33\% respectively. The ANOVA test indicates that the firms differ significantly for ROA. This implies that some of the firms are more profitable than the others.

\subsubsection{Independent Variables: Components of Working Capital (ADI, ADR, ADP, CCC)}

According to Table 2, the average number of days of inventories (ADI) for the five firms is 7.83 days, with L-LTD and S-LTD recording about 9 days as the highest number of days of inventories, while E-LTD, J-LTD and M-LTD recorded about 7 days of inventories, which is relatively low. The median ADI is around 8 days. These figures are lower than those reported in some previous studies (Charitou et al., 2010; Deloof, 2003; Shah \& Sana, 2005; Tauringana \& Afrifa, 2013).

In particular, the mean and median ADIs are far lower than the ADI mean of 21 days and median of 24 days found in Shah and Sana (2005) for seven listed firms in Pakistan's Oil and Gas industry. This implies that comparatively the sampled PRFs in Ghana appear to use about fewer than ten days to clear inventories, and are therefore more efficient in managing inventories better than their counterpart firms in Pakistan's Oil and Gas industry, who take approximately three weeks to clear inventories. One explanation for the sharp contrast is that those Pakistan companies were manufacturing companies while those used in this study are retailers. It has been established that retailers have shorter ADI than manufacturers that produce and sell mostly on credit (Uyar, 2009).

The average number of days accounts receivables (ADR) for the five sampled PRFs is approximately 34 days with a median of 36 days and standard deviation of about 10 days among the observations. For these results, while the median ADR is similar to those of Shah \& Sana (2005) for seven listed firms in Pakistan's Oil and Gas industry, the mean of 34 days ADR for the sampled PRFs in Ghana appears to be better than the mean ADR of 51.99 days (about one month and three weeks) for firms in Pakistan's Oil and Gas industry. This implies that the selected Ghanaian PRFs are more efficient in debt collection by taking relatively less number of days to collect their debts from customers than their counterparts in Pakistan Oil and Gas industry.

Table 2. Descriptive analysis for components of NWC for five sampled PRFs

\begin{tabular}{llll}
\hline \multicolumn{4}{l}{ ALL COMPANIES (five firms for six years) } \\
\hline Variable & Mean & Std. deviation & Median \\
\hline ROA & 17.32 & 13.02 & 17.50 \\
ADI & 7.83 & 2.57 & 8.00 \\
ADR & 33.93 & 9.66 & 36.00 \\
ADP & 11.70 & 4.63 & 12.50 \\
CCC & 29.37 & 10.20 & 32.00 \\
QR & 0.82 & 0.85 & 0.68 \\
ADI/CA & 0.37 & 0.13 & 0.36 \\
CA/TA & 0.89 & 0.15 & 0.94 \\
CA_TURN & 0.07 & 0.02 & 0.06 \\
LEV & 0.75 & 0.16 & 0.80 \\
TA & USD591430.00 & USD 439892.00 & USD 467843.91 \\
TALOG & 5.68 & 0.27 & 5.67 \\
\hline
\end{tabular}




\subsubsection{Controlled Variable: QR, ADI/CA, CA/TA, CA_TURN, LEV, TALOG}

According to Table 3, for the controlled variables, the results show that the mean quick ratio $(\mathrm{QR})$ for the five sample PRFs is 0.82 with a median ratio of 0.68 . These values are below at $1: 1$ ideal ratio for $Q R$. Since $Q R$ is an acid test ratio that is a more severe and stringent test of a firm's ability to pay its short-term obligations as and when they become due, the relatively low QR results imply that averagely the firms might be finding difficulties with their management of working capital (Arnold, 2008). Moreover, the results in Table 2 indicate that on average the inventory constitutes $3.7 \%$ ( 8.75 per cent) of the current assets (ADI/CA). The average current assets to total assets ratio is 0.89:1 (0.55:1) with a median value of 0.94:1. The current asset turnover (CA_TURN) is .07 (7.22) times. The average leverage (LEV) is 0.75 time, (2.23 times), with a median of 80 , whilst on average total assets of the sampled PRFs are worth USD 591430.00 with a median value of the total of USD 46783.91 suggests that the sampled firms are mostly small.

\subsection{Correlation Analysis for Dependent, Independent and Controlled Variables}

The results of Pearson correlation coefficients for dependent, independent and controlled variables are presented in Table 3. This analysis uses the combined data of all the five selected PRFs. The purpose is to assess the association between the CCC and its components (ADI, ADR and ADP) and profitability. The correlation results indicate a negative, but non-significant correlation between profitability and ADI, ADR and ADP. Among the independent variables, there are high and significant correlations between CCC and two measures of WCM, being QR, ADR, but not ADI and ADP. These are consistent with the findings of Tauringana and Afrifa (2013). It is worth noting that all the four components of WCM have a negative and significant relationship with QR.

Table 3. Correlation analysis for dependent, independent and controlled variables

\begin{tabular}{|c|c|c|c|c|c|c|c|c|c|c|c|c|}
\hline & ADI & ADR & ADP & $\mathrm{CCC}$ & ROA & QR & ADI/CA & CA/TA & CA_TURN & LEV & TALOG & VIF \\
\hline ADI & 1 & & & & & & & & & & & 6.278 \\
\hline $\mathrm{ADR}$ & 0.281 & 1 & & & & & & & & & & 5.769 \\
\hline ADP & $0.607 * * *$ & 0.328 & 1 & & & & & & & & & 2.793 \\
\hline $\mathrm{CCC}$ & 0.247 & $0.771 * * *$ & 0.003 & 1 & & & & & & & & 4.524 \\
\hline ROA & -0.206 & -0.048 & -0.280 & 0.045 & 1 & & & & & & & 7.415 \\
\hline QR & $-0.572 * *$ & $-0.527 * *$ & $-0.525^{*} *$ & $-0.396^{*}$ & 0.026 & 1 & & & & & & N/A \\
\hline $\mathrm{ADI} / \mathrm{CA}$ & $0.779 * * *$ & -0.001 & $0.436^{* *}$ & 0.060 & -0.027 & $-0.608 * * *$ & 1 & & & & & 2.151 \\
\hline CA/TA & 0.317 & 0.246 & $0.364^{* *}$ & 0.222 & 0.211 & $-0.363^{*}$ & $0.368^{*}$ & 1 & & & & 5.798 \\
\hline CA_TURN & 0.121 & 0.201 & 0.032 & 0.163 & -0.251 & -0.019 & -0.241 & $-0.721 * * *$ & 1 & & & 5.276 \\
\hline LEV & $0.427 *$ & $0.368^{*}$ & $0.538 * * *$ & 0.183 & 0.155 & $-0.819 * * * *$ & $0.446 * * *$ & $0.474 * * *$ & -0.098 & 1 & & 4.659 \\
\hline TALOG & 0.176 & $0.475^{* *}$ & $0.356^{*}$ & 0.226 & 0.202 & -0.324 & -0.067 & -0.083 & $0.499 * *$ & $0.353^{*}$ & 1 & 2.353 \\
\hline
\end{tabular}

Note. Significance levels $* * * \mathrm{p}<0001, * * \mathrm{p}<0.001, * \mathrm{p}<0.05$.

Table 4. Multilevel mixed-effects linear regression models

\begin{tabular}{lllll}
\hline Model summary & Model 1 (CCC on ROA) & Model 2 (ADI on ROA) & Model 3 (ADR on ROA) & Model 4 (ADP on ROA) \\
\hline No. of observation & 30 & 30 & 30 & 30 \\
Wald chi2(11) & $=62.54$ & $=66.62$ & $=65.41$ & $=75.50$ \\
Log likelihood & $=-102.160$ & $=-101.513$ & $=-101.701$ & $=-100.194$ \\
Prob> chi2 & $=0.0000$ & $=0.0000$ & $=0.0000$ & $=0.0000$ \\
Dependent variable & ROA & ROA & ROA & ROA \\
Model estimates & & & & \\
Independent variables & Co-efficient (z-score $)$ sig. & Co-efficient $(z$-score $)$ sig. & Co-efficient (z-score $)$ sig. & Co-efficient (z-score $)$ sig. \\
\hline Constant & $-148.424(-3.720)^{* * *}$ & $-189.209(-3.900)$ & $-145.903(-3.740)^{* * *}$ & $-166.483(-4.340)^{* * *}$ \\
CCC & $0.193(1.060)$ & $-3.479(-1.580)$ & $0.357(1.440)$ & $-1.197(-2.340)^{*}$ \\
QR & $10.079(2.450)^{*}$ & $8.536(2.390)^{* *}$ & $12.129(2.650)^{* *}$ & $7.508(2.200)^{*}$ \\
ADI/CA & $-4.310(-0.260)$ & $47.878(1.210)$ & $0.045(0.000)$ & $9.933(0.590)$ \\
CA/TA & $2.039(0.090)$ & $53.084(1.670)$ & $-0.136(-0.010)$ & $26.116(1.380)$ \\
CA_TURN & $-270.103(-2.040)^{*}$ & $30.933(0.150)$ & $-277.094(-2.160)^{*}$ & $-113.938(-0.920)$ \\
LEV & $44.093(2.380)^{* *}$ & $31.491(1.880)$ & $49.783(2.600)^{* *}$ & $35.029(2.210)^{*}$ \\
TALOG & $22.693(3.150)^{* *}$ & $23.039(3.270)^{* *}$ & $19.971(2.770)^{* *}$ & $24.632(3.620)^{* * *}$ \\
D_JLTD & $22.155(4.860)^{* * *}$ & $17.576(3.150)^{* *}$ & $25.519(5.370)^{* * *}$ & $15.786(3.030)^{* *}$ \\
D_LLTD & $10.282(2.100)^{*}$ & $12.516(2.580)^{*}$ & $12.178(2.510)^{*}$ & $8.041(1.700)$ \\
D_MLTD & $7.105(1.520)$ & $2.867(0.520)$ & $7.414(1.620)$ & $9.950(2.240)^{*}$ \\
D_SLTD & $-1.420(0.300)$ & $-6.000(-1.080)$ & $-0.046(-0.010)$ & $-3.070(-0.680)$ \\
\hline
\end{tabular}

Note. $* \mathrm{p}<0.05, * * \mathrm{p}<0.01, * * * \mathrm{p}<0.001$, Estimation method: Panel data Mixed-effects ML regression. 
The correlations among the remainder of the independent variables indicate that ADI positively correlates with ADP, negatively correlates with ADI/CA and LEV. While ADR positively correlates with LEV and total assets. ADP positively and significantly correlates with ADI/CA, CA/FA, LEV and total assets.

From the results in Table 3, the correlations also suggests that multicollinearity should not be a problem in the multiple regression analysis since the coefficient values are low. Hair et al. (2010) suggested that multicollinearity becomes a problem only when the correlation coefficient exceeds 0.80 or 0.90 . The results in Table 3 show that none of the correlations between independent variables exceeds these threshold values. In addition to the correlations, according to Cooper and Schindler (2006), a certain degree of multicollinearity can still exist even when none of the correlation coefficients are very large. Therefore, the variance inflation factors (VIFs) for the independent variables were also examined. A VIF of less than 10 suggests that multicollinearity does not pose a problem to the regressions (Field, 2005).

\section{Analysis of Results}

\subsection{Model Summary}

The results for each of the four models are presented in Table 4. It indicates that each of the four models are good since the Log likelihood values are all significant, meaning that all the independent variables collectively explain the dependent variable (ROA) significantly, and not by chance. The independent variables in each of the models collectively predict profitability well by $62.54 \%, 66.62 \%, 65.41 \%$, and $75.50 \%$, for models $1,2,3$ and 4 respectively.

\subsection{Effect of Predictors}

For model 1, the panel data Multilevel Mixed-effects linear regression results show that CCC is positively associated with ROA but the relationship is not significant. Therefore, hypothesis one (H1) is not supported. Despite the general non-significant CCC-ROA relationship, the firm effect or differences is significant variable. As can be seen, using firm E-LTD as the base, the co-efficient for dummy variables for firms for J-LTD (D_JLTD) is significant $(\beta=22.69, \mathrm{z}=3.15, \mathrm{p}=0.000)$. This implies that the strength of the effect of CCC on profitability is about 23 times stronger than in J-LTD more than it is in E-LTD. Similarly, the strength of the effect of CCC on profitability is about 10.28 times stronger than in L-LTD more than it is in E-LTD. These results suggests the relationship between CCC and profitability might be significant in some firms and non-significant in others.

For model 2, results show that ADI is negatively associated with ROA but the relationship is not significant. Therefore, hypothesis two (H2) is not supported. Despite this the general non-significant relationship ADI between ROA, the firm effect or differences is significant variable. As can be seen, using firm E-LTD as the base, the co-efficient for dummy variables for firms for J-LTD (D_JLTD) is significant $(\beta=17.58, z=3.15, p=0.002)$. This implies that the strength of the effect of ADI on profitability is about 17.58 times stronger than in J-LTD more than it is in E-LTD. Similarly, the strength of the effect of ADI on profitability is about 12.52 times stronger than in L-LTD more than it is in E-LTD. The results of CCC and ADI models are similar for these two firms (J-LTD and L-LTD), and suggest the relationship between ADI and profitability might be significant in some firms and non-significant in others. This implies that the firms might have different working capital needs, and pursing different WCM strategies and focus.

For model 3, the panel data Multilevel Mixed-effects linear regression results show that ADR is positively associated with ROA but the relationship is not significant. Despite this the general non-significant relationship ADR between ROA, the firm effect or differences is significant variable. As can be seen, using firm E-LTD as the base, the co-efficient for dummy variables for firms for J-LTD (D_JLTD) is significant $(\beta=25.519, \mathrm{z}=5.37, \mathrm{p}=$ 0.000). This implies that the strength of the effect of ADR on profitability is about 25.52 times stronger than in J-LTD more than it is in E-LTD. Similarly, the strength of the effect of ADR on profitability is about 12.17 times stronger than in L-LTD more than it is in E-LTD. The results of CCC, ADI and ADR are similar for these two firms, and suggest that the relationship between ADR and profitability might be significant in some firms and non-significant in others. This implies that the firms might have different working capital needs, and pursing different WCM strategies and focus.

For model 4, the panel data Multilevel Mixed-effects linear regression results show that ADP is negatively associated with ROA and the relationship is significant. Therefore, hypothesis four is supported. Thus ADP is the most significant factor in determining profitability in the sampled PRFs. The results also show that among the control variables, QR, LEV and TALOG are significantly associated with profitability at least at five per cent level. Despite this the general non-significant relationship ADR between ROA, the firm effect or differences is significant variable. As can be seen, using firm E-LTD as the base, the co-efficient for dummy variables for firms 
for J-LTD (D_JLTD) is significant $(\beta=15.786, \mathrm{z}=5.37, \mathrm{p}=0.002)$. This implies that the strength of the effect of ADP on profitability is about 15.79 times stronger than in J-LTD more than it is in E-LTD. Similarly, the strength of the effect of ADP on profitability is about 9.95 times stronger than in M-LTD more than it is in E-LTD. The results suggest that the relationship between ADP and profitability might be significant in some firms and non-significant in others. This implies that the firms might have different working capital needs, and pursing different WCM strategies and focus.

\section{Discussion of Results}

\subsection{Effect of CCC on Profitability (ROA)}

The results for testing hypothesis $\mathrm{H} 1$ show that CCC is positively associated with ROA but the relationship is not significant. This is similar to findings of Tauringana and Afrifa (2013) who found an insignificant association between CCC and profitability among SMEs in the UK. This finding on profitability and CCC is also consistent with the positive and non-significant relationship between CCC and profitability in Pakistan's Oil and Gas industry (Shah \& Sana, 2005).

However, the finding in respect of CCC and profitability relationship, which suggest an insignificant association with profitability, are contrary to most of the previous findings (Deloof, 2003; Stephen \& Elvis, 2011). Moreover, while this study found a positive association between CCC and profitability, it contradicts some previous studies found a negative relationship between WCM and CCC (Akoto et al., 2013; Lazaridis \& Tryfonidis, 2006; Falope \& Ajilore, 2009; Hayajneh \& Yassine, 2011; Karaduman et al., 2011).

These findings confirm that the influence of CCC on profitability vary from one industry and firm context to the other. Even within the same industry, there could be significant differences in the influence of CCC on profitability (Shah \& Sana, 2005; Vishnani \& Shah, 2007). The results also show that among the control variables, QR, CA_TURN and LEV are significantly associated with profitability at least at five per cent level, confirming previous research in other industries (Adjei \& Yeboah, 2011; Uyar, 2009).

Despite the general non-significant CCC-ROA relationship, the firm effect is significant variable. This implies that the firms might have different working capital needs, and pursing different WCM strategies and focus. This finding is supported those of previous studies (Falope \& Ajilore, 2009; Shah \& Sana 2005; Vishnani \& Shah, 2007) that found firm effect to be important and variations in WC-profitability relationship among various firm in different industries.

\subsection{Effect of ADI on Profitability (ROA)}

This study found that that ADI is negatively associated with ROA but the relationship is not significant. Therefore, hypothesis two (H2) is not supported. This is similar to findings of Tauringana and Afrifa (2013) among SMEs in the UK and those of Shah and Sana (2005) who found a negative and non-significant relationship between ADI and profitability in Pakistan's Oil and Gas industry. The results also show that among the control variables, QR and TALOG are significantly associated with profitability at least at five per cent level.

\subsection{Effect of ADR on Profitability ROA}

This study found that ADR is positively associated with ROA but the relationship is not significant. This is consistent with those of Shah and Sana (2005) who found a non-significant, but positive relationship between ADR and profitability in Pakistan's Oil and Gas industry.

However, the finding in respect of ADR and profitability relationship, which suggest an insignificant association with profitability, are contrary to most of the previous findings (e.g, Akoto et al., 2013; Deloof, 2003; Sharma \& Kumar, 2011; Tauringana \& Afrifa, 2013; Stephen \& Elvis, 2011). The results also show that among the control variables, QR, CA_TURN, LEV and TALOG are significantly associated with profitability at least at five per cent level.

Despite this the general non-significant relationship ADR between ROA, the firm effect or differences is significant variable. As can be seen, using firm E-LTD as the base, the co-efficient for dummy variables for firms for J-LTD (D_JLTD) is significant $(\beta=25.519, \mathrm{z}=5.37, \mathrm{p}=0.000)$. This implies that the strength of the effect of ADR on profitability is about 25.52 times stronger than in J-LTD more than it is in E-LTD. Similarly, the strength of the effect of ADR on profitability is about 12.17 times stronger than in L-LTD more than it is in E-LTD. The results of CCC, ADI and ADR are similar for these two firms, and suggest that the relationship between ADR and profitability might be significant in some firms and non-significant in others. This implies that the firms might have different working capital needs, and pursing different WCM strategies and focus. 


\subsection{Effect of ADP on Profitability (ROA)}

This study found that ADP is negatively associated with ROA and the relationship is significant. This implies the less the sampled firms delay in paying creditors, the more they increase profitability in terms of ROA. A reduction of ADP by -1.197 will cause a one percent increase in profitability of the firms. This is finding is similar to those of Adjei and Yeboah (2011); Falope and Ajilore (2009); Raheman and Nasr (2007); Sharma and Kumar (2011); and Tauringana and Afrifa (2013).

However, the finding on ADP and profitability relationship contrasts those of Gill et al. (2010) and Shah and Sana (2005). In particular, Shah and Sana (2005) found a non-significantly positive relationship between ADP and profitability in Pakistan's Oil and Gas industry. The results also show that among the control variables, QR, LEV and TALOG are significantly associated with profitability at least at five per cent level consistent with previous research (Sharma \& Kumar, 2011; Tauringana \& Afrifa 2013).

\section{Implications of the Study}

\subsection{Theoretical Implications}

This study is among the few that have examined WCM and profitability relationship in developing country petroleum industry, apart from the important study of Shah and Sana (2005). This study's findings appears to be consistent in many respect with a similar study by Shah and Sana (2005) in Pakistan's Oil and Gas industry. It, therefore, suggest that in the petroleum industry in Ghana, ADP appears to be the most significant factor in determining profitability, measured by ROA. Therefore, this study contributes to the literature on WCM in developing country in general and in petroleum industry in particular since there is no such study in the Sub-Sahara Africa and in Ghana, to the best of the researcher's knowledge.

Moreover, this study confirms that, theoretically the relationship between WCM components and profitability dependents may vary from one industry and context to another. Even within the same industry, there could be significant differences in the influence of CCC on profitability (Shah \& Sana, 2005; Vishnani \& Shah, 2007). For example, generally, while this study did not find supported for CCC, ADI, ADR and profitability confirming similar to findings in previous research (Tauringana \& Afrifa, 2013; Shah \& Sana, 2005), and at the same time contradicting other findings in some previous studies (Deloof, 2003; Tauringana \& Afrifa, 2013; Stephen \& Elvis, 2011). On the other hand, while this study found support for the relationship between ADP and profitability, which is similar to those of Adjei and Yeboah (2011), Falope and Ajilore (2009), Raheman and Nasr (2007), Sharma and Kumar (2011) and Tauringana and Afrifa (2013), this finding contradicts other studies that found a non-significantly positive relationship between ADP and profitability (Gill et al., 2010; Shah \& Sana, 2005).

Furthermore, the findings of this study indicate that WCM practices of the five selected PRFs support the conservative strategy of WCM. With the conservative strategy, a positive relationship should exist between CCC, ADI, ADR and profitability and a negative relationship between AP and profitability. Therefore, given the positive relationship between profitability and CCC, ADR and not ADI, and a negative effect of ADP on profitability, it depicts more of a conservative strategy, and not an aggressive WCM strategy (Tauringana \& Afrifa, 2013).

This study also found support for the controlled variables that can affect the estimation of firm profitability. Previous research indicates that many factors such as industry effect, firm effect, financial strategy effects as well as size of the firm (Tauringana \& Afrifa, 2013, p. 456). Consistent with prior research, this study has confirmed that factors such as quick ratio (QR), leverage (LEV) and firm size (TALOG) with the exception of ADI/CA and $\mathrm{CA} / \mathrm{TA})$.

\subsection{Managerial Implications}

The following are some recommendations to management for improving upon WCM in the PRFs. There is the need to improve management of average days of payables. Since the study found that ADP is negatively associated with profitability significantly, and is the only significant factor, management should pay more attention to ADP management and seek to improve upon it. According to the findings, the more the firms delay in paying creditors, the more they increase profitability in terms of ROA. Specifically, a reduction of ADP by -1.197 will cause a one percent increase in profitability of the firms.

Management of the firms should note that the significance of ADP on profitability occurred together with the significance of three control variables, QR, LEV and TALOG. Therefore, the management should seek to improve upon ADP together with QR, LEV and TALOG. While firm size (TALOG) is not easily changeable in the short-run, Quick ratio $(\mathrm{QR})$ and firm Leverage (LEV) should be improved significantly to boost profitability of the firms. For the individual firms, the strength of the effect of ADP on profitability is about 15.79 times stronger than in J-LTD more than it is in E-LTD. Similarly, the strength of the effect of ADP on profitability is about 9.95 times stronger 
than in M-LTD more than it is in E-LTD. The results suggest that the relationship between ADP and profitability might be significant in some firms and non-significant in others. This implies that the firms might have different working capital needs, and pursing different WCM strategies and focus.

\section{Conclusion}

The study examined the impact of WCM on profitability of selected PRFs in Ghana for the period of six years, 2008 to 2013. Based on objective analysis of the results and findings, this study concludes that, in the PRFs in Kumasi Metropolis, there is positive or favourable net working capital for the firms and a favourable networking capital to total assets ratio. The most important WCM component that drives the firm's profitability, measured in ROA, is average days payable (ADP). The rest of WCM components, CCC, ADI and ADR did not have significant relationship with profitability. While the findings of this study are consistent with many previous research, especially in a similar petroleum industry like Shah and Sana (2005), it contradicted the findings in some previous studies. The findings have important implications for both WCM theory and management of small and medium scale petroleum retail firms. Future research should be done to include a wider number of PRFs and firms from similar African contexts to provide a more generalizable findings, and compare the results with that found in this study. Moreover, the measure of profitability in this study was return on assets (ROA), future research should be done to find out the impact of WCM on other measures of profitability such as return on equity (ROE), firm growth and net trade cycle

\section{References}

Abosede, S. A., \& Luqman, O. S. (2014). A Comparative Analysis on Working Capital Management of Brewery Companies in Nigeria. http://dx.doi.org/10.2139/ssrn.2514668

Agyei, S. K., \& Yeboah, B. (2011). Working capital management and profitability of banks in Ghana. British Journal of Economics, Finance and Management Sciences, 2(2), 1-12.

Akoto, R. K., Awunyo-Vitor, D., \& Angmor, P. L. (2013). Working capital management and profitability: Evidence from Ghanaian listed manufacturing firms. Journal of Economics and International Finance, 5(9), 373-379. http://dx.doi.org/10.5897/JEIF2013.0539

Arnold, G. (2008). Corporate financial management (4th ed.). Harlow: Financial Times. Prentice Hall.

Arshad, Z., \& Gondal, M. (2013). Impact of working capital management on profitability: A case of the Pakistan cement industry. Interdisciplinary Journal of Contemporary Research in Business, 5(2), 384-390.

Aruldoss, S. P. S., Rajan, A. D., Jesus, R. F., \& Mohamed, M. (2013). A study on the working capital management of Bharat Petroleum Corporation Limited. International Journal of Research in Finance and Marketing, 2(5), 1-14.

Basics of Business Finance. (2004). Working capital finance (pp. 91-110). Retrieved on 15 March 2015 from http://www.sagepub.com/upm data/5005_Seidman_Chapter_5.pdf

Bevan, A. A., \& Danbolt, J. (2002). Capital structure and its determinants in the UK-a decompositional analysis. Applied Financial Economics, 12(3), 159-170. http://dx.doi.org/10.1080/09603100110090073

Cooper, D. R., \& Schindler P. S. (2006). Business Research Methods. New York: McGraw-Hill Irwin.

Deloof, M. (2003). Does working capital management affect profitability of Belgian firms? Journal of Business, Finance and Accounting, 30(3/4), 573-587. http://dx.doi.org/10.1111/1468-5957.00008

Hair, J. F., Black, W. C., Babin, B. J., \& Anderson, R. E. (2010). Multivariate Data Analysis. Englewood Cliffs, NJ: Prentice Hall.

Hayajneh, O. S., \& Yassine, F. L. A. (2011). The impact of working capital efficiency on profitability-an empirical analysis on Jordanian manufacturing firms. International Research Journal of Finance and Economics, 66, 61-76.

Jeng-Ren, C., Li, C., \& Han-Wen, W. (2006). The determinants of working capital management. Journal of American Academy of Business, Cambridge, 10(1), 149 -155.

Karaduman, H. A., Akbas, H. E., Caliskan, A. O., \& Durer, S. (2011). The relationship between working capital management and profitability: Evidence from an emerging market. International Research Journal of Finance and Economics, 62, 61-67.

Karaduman, H. A., Akbas, H. E., Ozsozgun, A., \& Durer, S. (2010). Effect of working capital management on profitability: The case for selected companies in the Istanbul Stock Exchange (2005-2008). International 
Journal of Economics and Financial Studies, 2(2), 47-54.

Kastning, T. (2011). Basic Overview of Ghana's Emerging Oil Industry. FES Ghana, 1-20. Retrieved 10 March 2015 from http://www.fesghana.org/uploads/PDF/BasicOverview Oil Economy Ghana 2011.pdf

Khan, M., \& Jain, P. K. (2007). Management accounting: Text, problems and causes (4th ed.). New Delhi: Tata McGraw-Hill.

Lazaridis, I., \& Tryfonidis, D. (2006). Relationship between working capital management and profitability of listed companies in the Athens stock exchange. Journal of Financial Management and Analysis, 19(1), 26-35.

Ministry of Energy. (2010). Energy sector strategy and development plan. Retrieved on 10 March 2015 from http://ghanaoilwatch.org/images/laws/energy_strategy.pdf

Offshore-Technology.com. (2011). Jubilee Field, Ghana. Retrieved from http://www.offshoretechnology.com

Oladipupo, A. O., \& Okafor, C. A. (2013). Relative contribution of working capital management to corporate profitability and dividend payout ratio: Evidence from Nigeria. International Journal of Business and Finance Research, 3(2), 11-20.

Orobia, L. A., Byabashaija, W., Munene, J. C., Sejjaaka, S. K., \& Musinguzi, D. (2013). How do small business owners manage working capital in an emerging economy? A qualitative inquiry. Qualitative Research in Accounting and Management, 10(2), 127-143. http://dx.doi.org/10.1108/QRAM-02-2012-0008

Overview of global economic development and Ghana's economic performance. (2014). Retrieved 22 February 2015 from http://isser.edu.gh/files/Press_Kit.pdf

Padachi, K. (2006). Trends in working capital management and its impact on firms' performance -An analysis of Mauritian small manufacturing firms. International Review of Business Research Papers, 2(2), 45-58

Raza, M. Y., Bashir, M., Latif, K., \& Shah, T. S. (2015). Impact of working capital management on profitability: Evidence from Pakistan oil sector. International Journal of Accounting and Financial Reporting, 5(1), 286-299. http://dx.doi.org/10.5296/ijafr.v5i1.7825

Sarkar, C. R., \& Sarkar, A. (2013). Impact of Working Capital Management on Corporate Performance: An Empirical Analysis of Selected Public Sector Oil and Gas Companies in India. International Journal of Financial Management, 3(2), 17.

Shah, S. A., \& Sana, A. (2005). Impact of working capital management on the profitability of oil and gas sector of Pakistan. European Journal of Scientific Research, 15(3), 301-307.

Sharma, A. K., \& Kumar, S. (2011). Effect of working capital management on firm profitability empirical evidence from India. Global Business Review, 12(1), 159-173. http://dx.doi.org/10.1177/097215091001200110

Sogorb-Mira, F. (2005). How SME uniqueness affects capital structure: Evidence from a 1994-1998 Spanish data panel. Small Business Economics, 25(5), 447-457. http://dx.doi.org/10.1007/s11187-004-6486-8

Stephen, M., \& Elvis, K. (2011). Influence of working capital management on firms profitability: A case study of SMEs in Kenya. International Business Management, 5, 279-286. http://dx.doi.org/10.3923/ibm.2011.279.286

Tauringana, V., \& Afrifa, A. (2013). The relative importance of working capital management and its components to SMEs' profitability. Journal of Small Business and Enterprise Development, 20(3), 453-469. http://dx.doi.org/10.1108/JSBED-12-2011-0029

Zawaira, T., \& Mutenheri, E. (2014). The association between working capital management and profitability of non-financial companies listed on the Zimbabwe stock exchange. International Journal, 3(8), 2307-227X.

African Economic Outlook (AEO). (2014). Retrieved on 22 February 2015 from http://www.africaneconomicoutlook.org/fileadmin/uploads/aeo/2014/PDF/CN_Long_E/Ghana_ENG.pdf

\section{Copyrights}

Copyright for this article is retained by the author(s), with first publication rights granted to the journal.

This is an open-access article distributed under the terms and conditions of the Creative Commons Attribution license (http://creativecommons.org/licenses/by/3.0/). 